\title{
The Ocean and Cryosphere in a Changing Climate
}

Special Report of the Intergovernmental Panel on Climate Change

\section{Edited by}

\author{
Hans-Otto Pörtner \\ Working Group II Co-Chair \\ Valérie Masson-Delmotte \\ Working Group I Co-Chair
}

\author{
Debra C. Roberts \\ Working Group II Co-Chair \\ Panmao Zhai \\ Working Group I Co-Chair
}

Melinda Tignor

Head of WGII TSU

Andrés Alegría

Graphics Officer

Jan Petzold

Science Officer
Elvira Poloczanska

Science Advisor to the WGII

Co-Chairs and TSU

Maike Nicolai

Communications Officer

Bardhyl Rama

Director of Operations
Katja Mintenbeck

Director of Science

Andrew Okem

Science Officer

Nora M. Weyer

Science Officer

Working Group II Technical Support Unit 


\section{CAMBRIDGE \\ UNIVERSITY PRESS}

University Printing House, Cambridge CB2 8BS, United Kingdom

One Liberty Plaza, 20th Floor, New York, NY 10006, USA

477 Williamstown Road, Port Melbourne, VIC 3207, Australia

314-321, 3rd Floor, Plot 3, Splendor Forum, Jasola District Centre, New Delhi - 110025, India

103 Penang Road, \#05-06/07, Visioncrest Commercial, Singapore 238467

Cambridge University Press is part of the University of Cambridge.

It furthers the University's mission by disseminating knowledge in the pursuit of education, learning, and research at the highest international levels of excellence.

www.cambridge.org

Information on this title: www.cambridge.org/9781009157971

DOI: $10.1017 / 9781009157964$

(C) Intergovernmental Panel on Climate Change 2022

This work is in copyright. It is subject to statutory exceptions and to the provisions of relevant licensing agreements; with the exception of the Creative Commons version the link for which is provided below, no reproduction of any part of this work may take place without the written permission of Cambridge University Press.

An online version of this work is published at doi.org/10.1017/9781009157964 under a Creative Commons Open Access license CC-BY-NC-ND 4.0 which permits re-use, distribution and reproduction in any medium for non-commercial purposes providing appropriate credit to the original work is given. You may not distribute derivative works without permission. To view a copy of this license, visit https://creativecommons.org/licenses/by-nc-nd/4.0

All versions of this work may contain content reproduced under license from third parties.

Permission to reproduce this third-party content must be obtained from these third-parties directly.

When citing this work, please include a reference to the DOI 10.1017/9781009157964

First published 2022

Printed in the United Kingdom by TJ Books Limited, Padstow Cornwall

A catalogue record for this publication is available from the British Library.

ISBN 978-1-009-15797-1 Paperback

Cambridge University Press has no responsibility for the persistence or accuracy of URLs for external or third-party internet websites referred to in this publication and does not guarantee that any content on such websites is, or will remain, accurate or appropriate.

This report should be cited as:

IPCC, 2019: IPCC Special Report on the Ocean and Cryosphere in a Changing Climate [H.-O. Pörtner, D.C. Roberts, V. Masson-Delmotte, P. Zhai, M. Tignor, E. Poloczanska, K. Mintenbeck, A. Alegría, M. Nicolai, A. Okem, J. Petzold, B. Rama, N.M. Weyer (eds.)]. Cambridge University Press, Cambridge, UK and New York, NY, USA, 755 pp. https://doi.org/10.1017/9781009157964.

The designations employed and the presentation of material on maps do not imply the expression of any opinion whatsoever on the part of the Intergovernmental Panel on Climate Change concerning the legal status of any country, territory, city or area or of its authorities, or concerning the delimitation of its frontiers or boundaries.

Front and back cover artwork and layout by Stefanie Langsdorf 